\title{
EXPERIMENTAL STUDY OF EFFECT OF PRESSURE ON PYROLYSIS OF BIOMASS
}

\author{
Vaishali S. Waghmare ${ }^{1}$, Ganesh R. Kale ${ }^{2}$, Girish M. Deshmukh ${ }^{3}$, Suhas D. Doke ${ }^{4}$

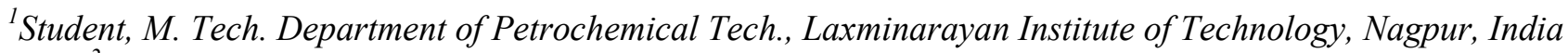 \\ ${ }^{2}$ Senior Scientist, Solid and Hazardous Waste Management Division, CSIR-NEERI, Nagpur, India \\ ${ }^{3}$ Associate Professor, Department of Petrochemical Tech., Laxminarayan Institute of Technology, Nagpur, India \\ ${ }^{4}$ Junior Research Fellow, Solid and Hazardous Waste Management Division, CSIR-NEERI, Nagpur, India
}

\begin{abstract}
Pyrolysis is thermal treatment of solid waste in the absence of an oxidizing agent (in inert atmosphere) which generally yields three products namely pyrolysis-oil (liquid), char (solid residue) and gas. The products obtained in pyrolysis can be further used as energy source. Rice husk and saw dust are considered as solid wastes in this study. The effect of temperature and pressure on pyrolysis was studied in a fixed bed reactor. The experimental runs were performed in nitrogen atmosphere. The temperature was varied from $300^{\circ} \mathrm{C}$ to $500^{\circ} \mathrm{C}$, while the operational pressure was fixed at 4 bar, 7 bar and 10 bar. The products such as solid char, liquid pyrolysis oil and syngas were obtained. The solid char was characterized by CHNS analysis, while the pyrolysis oil was characterized by FTIR analysis,
\end{abstract}

Keywords- Rice Husk; Saw Dust, Pyrolysis; Pyrolysis-Oil; Char;

\section{INTRODUCTION}

Rigorous research on renewable energy sources is gaining attention for upcoming energy systems. Biomass has a great potential to replace the usual energy sources [1]. Only small amount of agro-waste biomass is used as feed in animal husbandry and huge amount of biomass is dumped into fields and landfills or used as paving material that causes environmental problems [2]. Pyrolysis is a type of thermal treatment that converts biomass in liquid (pyrolysis-oil), char, and syngas in absence of oxygen [3]. Biomass can be pyrolyzed to yield solid char, liquid pyrolysis oil, and syngas which may be used as fuels and chemicals for various purposes [4]. Pyrolysis is nowadays, a new type of solid waste utilization technique for transformation of biomass and waste material of low-energy density into pyrolysis oil of high-energy density with recovery of higher value chemicals [5]. Bio-char may also be used for soil amendments [6]. Biomass such as rice husk and sugarcane bagasse are preferred due to ease of availability, collection and transportation and are used in boilers for combustion [7].

The pyrolysis oils are composed of a range of chemicals including cyclopentanone, methoxy phenol, acetic acid, methanol, acetone, furfural, phenol (aromatic ring), formic acid, levoglucosan, guaiacol and their alkylated phenol derivatives. The structural components of the biomass samples mainly affect the products of pyrolytic degradation $[8,9]$. The major components of gas evolved during pyrolysis were $\mathrm{CO}, \mathrm{CO}_{2}$ and $\mathrm{H}_{2} \mathrm{O}$ at lower temperatures, while lower concentrations of $\mathrm{CO}, \mathrm{CO}_{2}, \mathrm{H}_{2} \mathrm{O}, \mathrm{H}_{2}$, and $\mathrm{CH}_{4}$, $\mathrm{C}_{2} \mathrm{H}_{6}$ and oil were evolved at higher temperatures [10]. The pyrolysis temperature has a significant effect on product distribution, while heating rate plays a less effective role on product distribution and yields of products. For example in case of waste paper, it has been reported that the pyrolysis oil yield was $49.13 \%$ at $420^{\circ} \mathrm{C}$ with heating rate of $30^{\circ} \mathrm{C}$ $\mathrm{min}^{-1}$ than at lower temperatures [11]. Particle size also plays an important role in product yield. Islam et. al. have reported that the pyrolysis of nutshells yielded maximum oil at $500^{\circ} \mathrm{C}$ for feed size of $300-600 \mu \mathrm{m}$ [12]. Punsuwan et al. have identified effect of temperature $\left(250-1050^{\circ} \mathrm{C}\right)$ and particle size $(0.18-1.55 \mathrm{~mm})$ on yield of pyrolysis products in palm shell, palm kernel and cassava pulp concluded that higher temperature and smaller particle size caused an increase in the gas yield with decrease in the char yield [13]. It has also been reported that the presence of moisture affects the char yield [14].

Some researchers have reported a $52 \%$ pyrolysis oil yield at $400^{\circ} \mathrm{C}$ from pyrolysis of waste cup and their FTIR results showed that oil contained C6-C20 carbon chain compounds [5]. While another result showed that a linear chain of hydrocarbons (C13-C25) was obtained [15]. Similarly pyrolysis of bicycle tire at $600^{\circ} \mathrm{C}$ yielded $49 \%$ pyrolysis oil at heating rate of $20^{\circ} \mathrm{C} / \mathrm{min}$ [16]. Pyrolysis of para rubber seeds yielded $38.22 \%$ pyrolysis oil at $450^{\circ} \mathrm{C}$, having calorific values $22.11 \mathrm{MJ} / \mathrm{kg}$ [17]. Some researchers have reported that the pyrolysis of jack fruit peels yielded $52.6 \%$ pyrolysis oil within the temperature range of $400^{\circ} \mathrm{C}$ to $600^{\circ} \mathrm{C}$ [18]. Guo et. al have reported that the thermal stability of pyrolysis oil was better in the light fraction, but worse in the middle and heavy fractions [19]. Another research showed that, fast pyrolysis at constant high temperature favored maximum oil yield and decreased char yield [20]. Some researchers have reported that catalytic (ZSM-5 catalyst) pyrolysis of rice husk, yielded less liquid of reduced oxygenated content [21]. High pressure pyrolysis 
favored formation of a foam type of char structure and char formation decreased under pressurized conditions [22]. Melligan et al. have reported the pyrolysis of miscanthus $\mathrm{x}$ gigantues from ambient pressure to 26 bar pressure, in nitrogen atmosphere and ambient temperature to $550^{\circ} \mathrm{C}$ at rate of $13^{\circ} \mathrm{C} / \mathrm{min}$ showed that the pyrolysis oil was formed with water and phenol derivatives [23].

\section{EXPERIMENTAL METHODOLOGY}

The feed material for pyrolysis was collected from various sources. The rice husk sample was obtained from a rice mill from Chhattisgarh, India; while the saw dust samples taken from local carpentry shop, Nagpur. The proximate and ultimate analysis of rice husk and saw dust were done and the results are shown is shown in table 1 and table 2 . Table 3 shows the experimental conditions.

Table 1: Proximate analysis of rice husk and saw dust

\begin{tabular}{|l|l|l|}
\hline Characteristics & Rice husk & Saw dust \\
\hline Moisture & $6.47 \%$ & $6.50 \%$ \\
\hline Combustible Matter & $81.90 \%$ & $80.19 \%$ \\
\hline Ash & $11.71 \%$ & $11.81 \%$ \\
\hline
\end{tabular}

Table 2: Ultimate analysis of rice husk and saw dust

\begin{tabular}{|l|l|l|}
\hline \multirow{2}{*}{ Component } & \multicolumn{2}{|l|}{$\%$ by weight dry ash free basis } \\
\cline { 2 - 3 } & Rice husk & Saw dust \\
\hline $\mathrm{C}$ & $48.69 \%$ & $47.20 \%$ \\
\hline $\mathrm{H}$ & $6.97 \%$ & $6.50 \%$ \\
\hline $\mathrm{N}$ & $0.37 \%$ & $0.012 \%$ \\
\hline $\mathrm{O}$ & $43.94 \%$ & $45.40 \%$ \\
\hline
\end{tabular}

Table 3: Experimental conditions of pyrolysis of rice husk and saw dust

\begin{tabular}{|l|l|l|l|}
\hline $\begin{array}{l}\text { Run } \\
\text { No. }\end{array}$ & Feed & $\begin{array}{l}\text { Temperature } \\
\left({ }^{\circ} \mathbf{C}\right)\end{array}$ & $\begin{array}{l}\text { Pressure } \\
\text { (bar) }\end{array}$ \\
\hline $\mathbf{1}$ & Rice husk & $400^{\circ} \mathrm{C}$ & 4 bar \\
\hline $\mathbf{2}$ & Rice husk & $400^{\circ} \mathrm{C}$ & 7 bar \\
\hline $\mathbf{3}$ & Rice husk & $400^{\circ} \mathrm{C}$ & 10 bar \\
\hline $\mathbf{4}$ & Saw dust & $400^{\circ} \mathrm{C}$ & 4 bar \\
\hline $\mathbf{5}$ & Saw dust & $400^{\circ} \mathrm{C}$ & 7 bar \\
\hline $\mathbf{6}$ & Saw dust & $400^{\circ} \mathrm{C}$ & 10 bar \\
\hline $\mathbf{7}$ & Saw dust & $500^{\circ} \mathrm{C}$ & 4 bar \\
\hline $\mathbf{8}$ & Saw dust & $500^{\circ} \mathrm{C}$ & 7 bar \\
\hline $\mathbf{9}$ & Saw dust & $500^{\circ} \mathrm{C}$ & 10 bar \\
\hline $\mathbf{1 0}$ & Rice husk & $300^{\circ} \mathrm{C}$ & 7 bar \\
\hline $\mathbf{1 1}$ & Rice husk & $400^{\circ} \mathrm{C}$ & 7 bar \\
\hline $\mathbf{1 2}$ & Rice husk & $500^{\circ} \mathrm{C}$ & 7 bar \\
\hline
\end{tabular}

\subsection{Experimental Procedure}

The pyrolysis of rice husk and saw dust was done in a fixed bed reactor system. The reactor tube had one gas inlet on the top side that was used for passing nitrogen gas in the reactor. An inconel tube reactor of dimensions $600 \mathrm{~mm}$ in length and $52 \mathrm{~mm}$ diameter was used; in which the length of the heating zone was $500 \mathrm{~mm}$. All the experimental runs were carried out in nitrogen (inert) atmosphere. An electrical furnace with auto tuning PID controller and K-type thermocouples was used for heating the inconel reactor. A back pressure regulator was used to monitor and control the reaction pressure. Samples of 75 gms were used in each experiment, while the residence time was fixed at 2 hours. The pyrolysis of biomass samples was performed at three pressure separately i.e. 4 bar, 7 bar and 10 bar, at $400^{\circ} \mathrm{C}$, while in some cases the temperature of $300^{\circ} \mathrm{C}$ and $500^{\circ} \mathrm{C}$ were also tried. Figure 1 shows the experimental setup for pyrolysis.

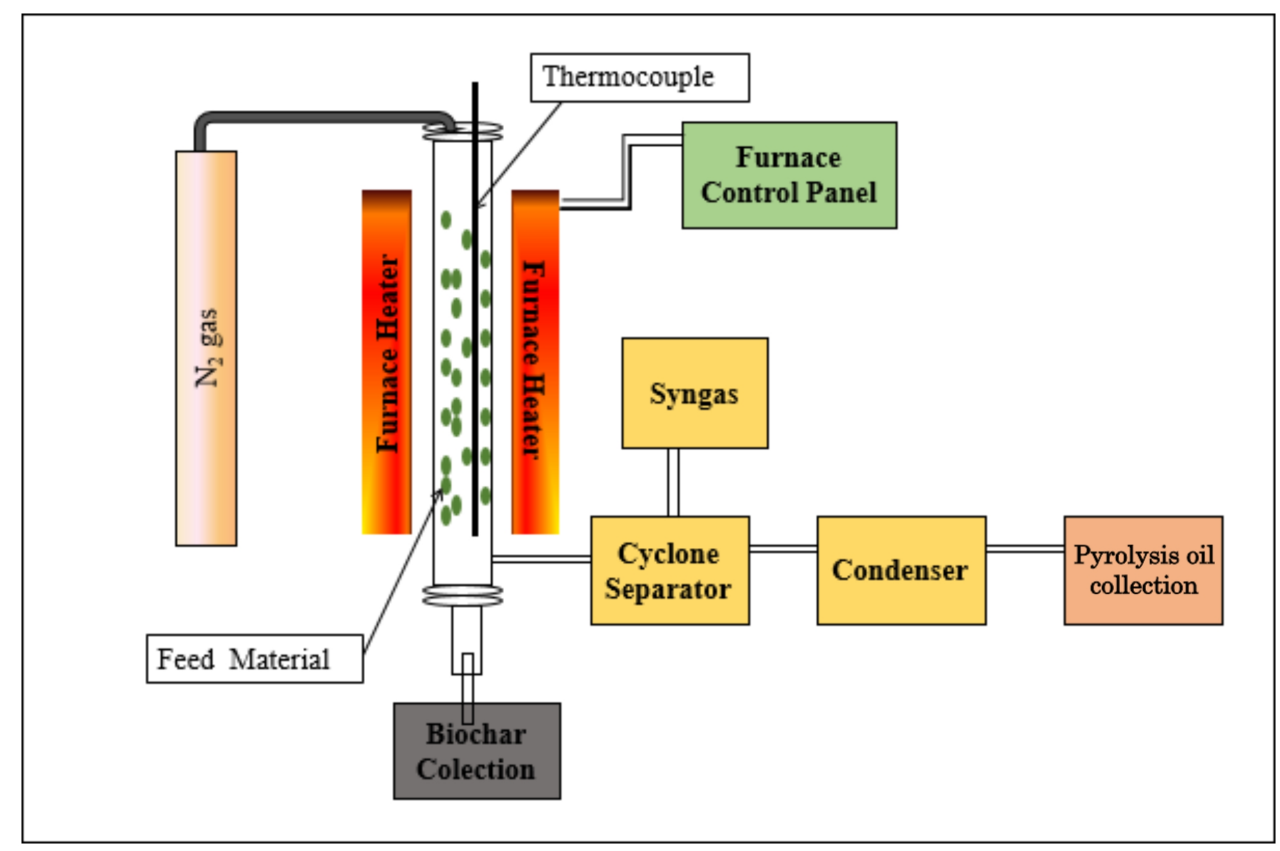

Fig 1: Fixed Bed Reactor Unit 
The products were discharged in gas solid separator (cyclone separator), and then finally passed through chilled water condenser.

\section{RESULT AND DISCUSSION}

\subsection{Product Distribution}

In general it was observed that the pyrolysis yielded three different products as solid (char), liquid (pyrolysis oil) and gaseous (syngas). The figure 2 shows products obtained in pyrolysis of biomass (saw dust).

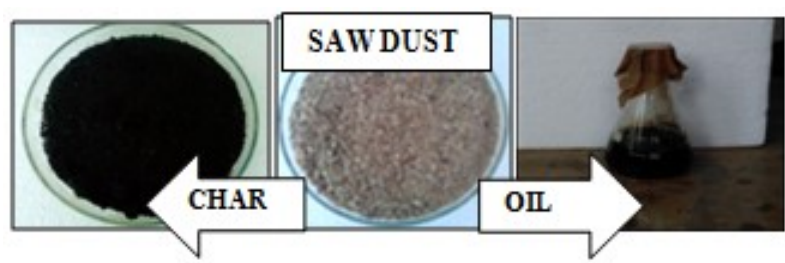

Fig 2: Product yield in pyrolysis of biomass (Saw dust)

\subsection{Product Analysis and Characterization}

Yield of each pyrolysis products was calculated by following formula:

$$
\begin{aligned}
& \text { Liquid Yield }=\frac{\text { Weight of Liquid Product }}{\text { Weight of initial pyrolysis material }} \times 100 \% \\
& \text { Solid Yield }=\quad \frac{\text { Weight of Solid Product }}{\text { Weight of initial pyrolysis material }} \times 100 \%
\end{aligned}
$$

$\%$ yield of gas product $=\mathbf{1 0 0}-\{(\%$ yield of liq. prod. $)+$ (\% yield of solid product.)

The percentage of product yield was calculated at respective experimental condition shown in table 4 .

Table 4: Product distribution of pyrolysis of rice husk and saw dust.

\begin{tabular}{|l|l|l|l|l|l|}
\hline Run No. & Feed & Feed conditions & Solid (\%) & Liquid (\%) & Gas (\%) \\
\hline $\mathbf{1}$ & Rice husk & $400^{\circ} \mathrm{C}, 4$ bar & 49.53 & 14.66 & 35.81 \\
\hline $\mathbf{2}$ & Rice husk & $400^{\circ} \mathrm{C}, 7$ bar & 52.86 & 17.60 & 29.54 \\
\hline $\mathbf{3}$ & Rice husk & $400{ }^{\circ} \mathrm{C}, 10$ bar & 49.21 & 26.40 & 24.39 \\
\hline $\mathbf{4}$ & Saw dust & $400{ }^{\circ} \mathrm{C}, 4$ bar & 32.13 & 21.97 & 45.9 \\
\hline $\mathbf{5}$ & Saw dust & $400^{\circ} \mathrm{C}, 7$ bar & 32.00 & 23.81 & 44.19 \\
\hline $\mathbf{6}$ & Saw dust & $400^{\circ} \mathrm{C}, 10$ bar & 31.73 & 27.48 & 40.79 \\
\hline $\mathbf{7}$ & Saw dust & $500^{\circ} \mathrm{C}, 4$ bar & 30.93 & 23.81 & 45.26 \\
\hline $\mathbf{8}$ & Saw dust & $500^{\circ} \mathrm{C}, 7$ bar & 29.94 & 25.64 & 44.42 \\
\hline $\mathbf{9}$ & Saw dust & $500^{\circ} \mathrm{C}, 10$ bar & 30.13 & 27.48 & 42.39 \\
\hline $\mathbf{1 0}$ & Rice husk & $300^{\circ} \mathrm{C}, 7$ bar & 63.58 & 22.00 & 14.42 \\
\hline $\mathbf{1 1}$ & Rice husk & $400^{\circ} \mathrm{C}, 7$ bar & 44.86 & 19.06 & 36.08 \\
\hline $\mathbf{1 2}$ & Rice husk & $500^{\circ} \mathrm{C}, 7$ bar & 32.29 & 14.66 & 53.05 \\
\hline
\end{tabular}

Table 4 shows the variation in the weight of liquid, char and gaseous products at different temperatures. In case of rice husk samples, the maximum liquid product yield was obtained at $300^{\circ} \mathrm{C}$ and 7 bar.

\subsubsection{Effect of Pressure}

Table 5 shows the effect of pressure on the pyrolysis biomass (rice husk and saw dust). The operating pressure was fixed as 4 bar, 7 bar and 10 bar, while temperature was maintained constant. The liquid product yield was highest at higher pressure (10 bar) at all temperature conditions in cases (run 3, 6, 9 respectively). It was also seen from the result that high pressure favored increase in yield of the liquid product.

Table 5: Effect of pressure on pyrolysis of rice husk and saw dust.

\begin{tabular}{|l|l|l|l|l|l|}
\hline Run No. & Feed & Char weight $(\mathbf{g m})$ & Liquid $(\mathbf{m l})$ & Combustible Liquid (ml) & Time (hr) \\
\hline $\mathbf{1}$ & Rice husk & $37.15 \mathrm{gm}$ & $18 \mathrm{ml}$ & $10 \mathrm{ml}$ & $2 \mathrm{hr}$ \\
\hline $\mathbf{2}$ & Rice husk & $39.65 \mathrm{gm}$ & $20 \mathrm{ml}$ & $12 \mathrm{ml}$ & $2 \mathrm{hr}$ \\
\hline $\mathbf{3}$ & Rice husk & $36.91 \mathrm{gm}$ & $22 \mathrm{ml}$ & $18 \mathrm{ml}$ & $2 \mathrm{hr}$ \\
\hline $\mathbf{4}$ & Saw dust & $24.10 \mathrm{gm}$ & $22 \mathrm{ml}$ & $12 \mathrm{ml}$ & $2 \mathrm{hr}$ \\
\hline $\mathbf{5}$ & Saw dust & $24.00 \mathrm{gm}$ & $24 \mathrm{ml}$ & $13 \mathrm{ml}$ & $2 \mathrm{hr}$ \\
\hline $\mathbf{6}$ & Saw dust & $23.80 \mathrm{gm}$ & $26 \mathrm{ml}$ & $15 \mathrm{ml}$ & $2 \mathrm{hr}$ \\
\hline $\mathbf{7}$ & Saw dust & $23.20 \mathrm{gm}$ & $23 \mathrm{ml}$ & $13 \mathrm{ml}$ & $2 \mathrm{hr}$ \\
\hline $\mathbf{8}$ & Saw dust & $22.46 \mathrm{gm}$ & $25 \mathrm{ml}$ & $14 \mathrm{ml}$ & $2 \mathrm{hr}$ \\
\hline $\mathbf{9}$ & Saw dust & $22.60 \mathrm{gm}$ & $27 \mathrm{ml}$ & $15 \mathrm{ml}$ & $2 \mathrm{hr}$ \\
\hline
\end{tabular}




\subsubsection{Effect of Temperature}

Table 6 shows the effect of temperature on pyrolysis of rice husk, (Run 10,11, 12). It is seen that with the increase in temperature; the syngas yield increased but the char yield decreased.

Table 6: Effect of temperature in pyrolysis of rice husk

\begin{tabular}{|l|l|l|l|l|l|}
\hline Run No. & Feed & Char weight (gm) & Liquid (ml) & Combustible Liquid (ml) & Time (hr) \\
\hline $\mathbf{1 0}$ & Rice husk & $47.69 \mathrm{gm}$ & $24 \mathrm{ml}$ & $15 \mathrm{ml}$ & $2 \mathrm{hr}$ \\
\hline $\mathbf{1 1}$ & Rice husk & $33.65 \mathrm{gm}$ & $20 \mathrm{ml}$ & $13 \mathrm{ml}$ & $2 \mathrm{hr}$ \\
\hline $\mathbf{1 2}$ & Rice husk & $24.22 \mathrm{gm}$ & $18 \mathrm{ml}$ & $10 \mathrm{ml}$ & $2 \mathrm{hr}$ \\
\hline
\end{tabular}

\subsection{Characterization of Pyrolysis Oil}

\subsubsection{Physical Properties of Pyrolysis Oil}

The physical properties of pyrolysis oil obtained at different pressures in pyrolysis of rice husk and saw dust are shown in table 7.

Table 7: Properties of pyrolysis oil from rice husk and saw dust.

\begin{tabular}{|l|l|l|l|}
\hline Sr. no. & Properties & Rice husk & Saw dust \\
\hline $\mathbf{1}$ & pH & 3.1 & 3.4 \\
\hline $\mathbf{2}$ & Density & $1.1 \mathrm{gm} / \mathrm{ml}$ & $1.38 \mathrm{gm} / \mathrm{ml}$ \\
\hline $\mathbf{3}$ & Viscosity $\mathbf{4 0}^{\circ} \mathrm{C}$ & $120 \mathrm{red}$ wood seconds & $126 \mathrm{red}$ wood seconds \\
\hline $\mathbf{4}$ & Solid & $22 \%$ & $21.45 \%$ \\
\hline $\mathbf{5}$ & Ash & $9.12 \%$ & $9.736 \%$ \\
\hline $\mathbf{6}$ & Water & $43 \%$ & $43.34 \%$ \\
\hline $\mathbf{7}$ & Flash point & $62^{\circ} \mathrm{C}$ & $61^{\circ} \mathrm{C}$ \\
\hline $\mathbf{8}$ & Pour point & Below $-1^{\circ} \mathrm{C}$ & Below- $1^{\circ} \mathrm{C}$ \\
\hline
\end{tabular}

\subsubsection{Chemical Properties of Pyrolysis oil.}

\subsubsection{FTIR Analysis of Pyrolysis oil}

The results of FTIR analysis of pyrolysis oil are shown in figures 3, 4 and 5. It shows the functional groups present in the oil. Table 8 shows the functional groups present in pyrolysis oil at different pressure and temperature conditions. The functional groups show the presence of hydrocarbon and organic components in the oil. Hence pyrolysis oil may useful as chemical feed stock or as fuel.

\subsection{Pyrolysis oil analysis at $500{ }^{\circ} \mathrm{C}$ and 7 bar}

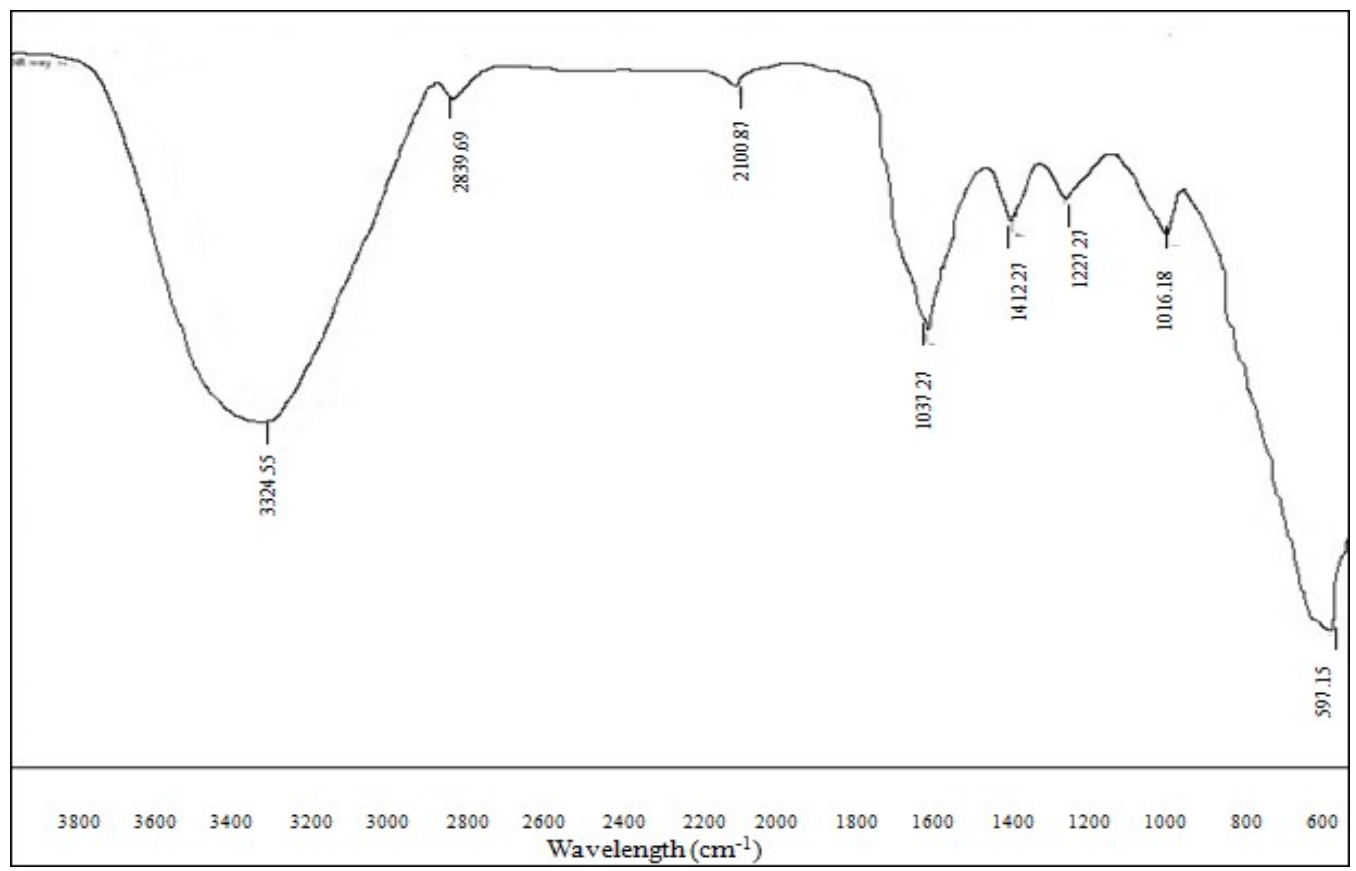

Fig 3: FTIR result of saw dust pyrolysis oil (At $500^{\circ} \mathrm{C}$ and $\mathrm{P}=7$ bar) 


\subsection{Pyrolysis oil analysis at $400^{\circ} \mathrm{C}$ and $10 \mathrm{bar}$}

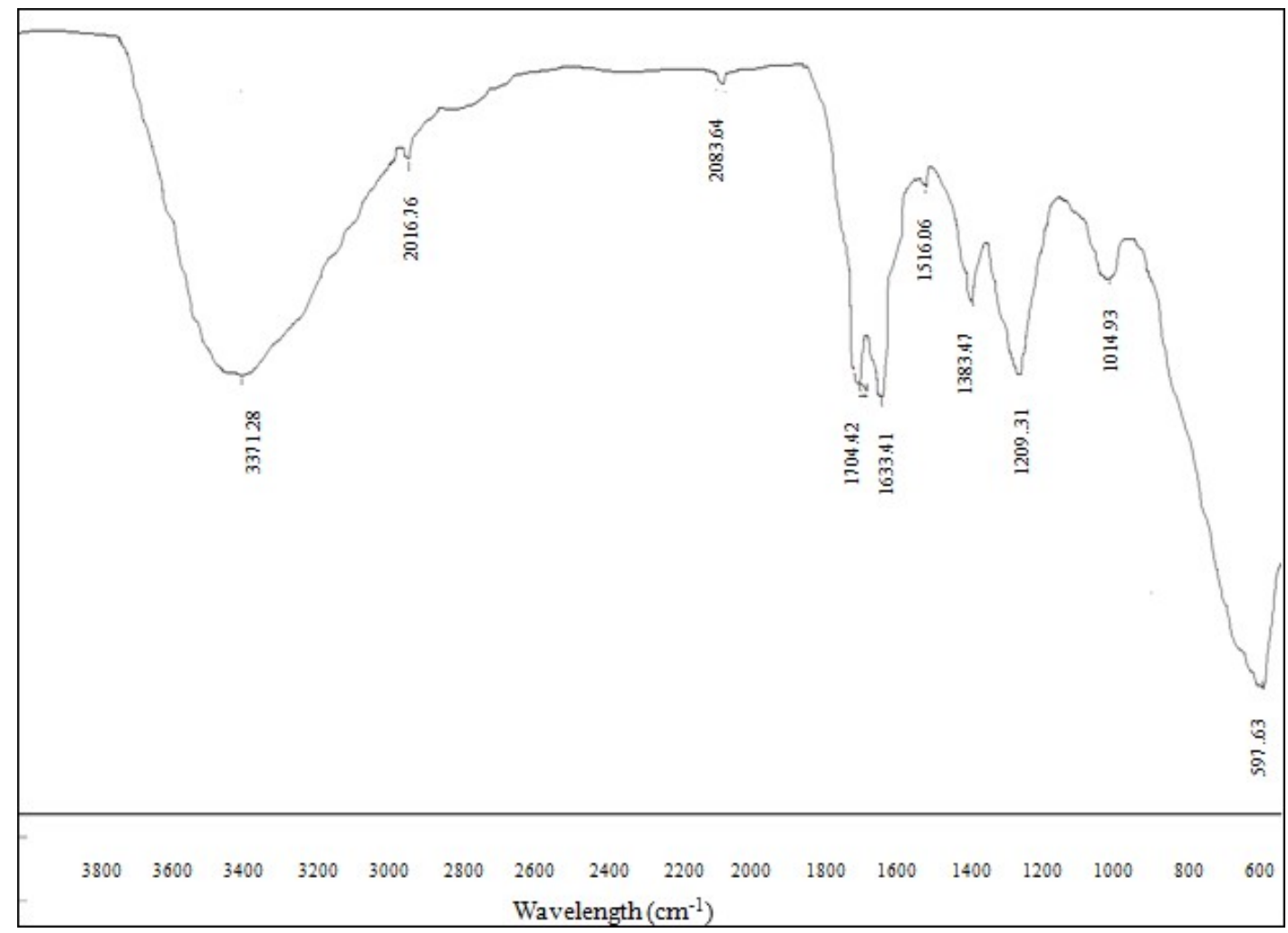

Fig 4: FTIR result of rice husk pyrolysis oil $\left(400^{\circ} \mathrm{C}\right.$ and $\mathrm{P}=10$ bar $)$

\subsection{Pyrolysis oil analysis at $500{ }^{\circ} \mathrm{C}$ and 10 bar}

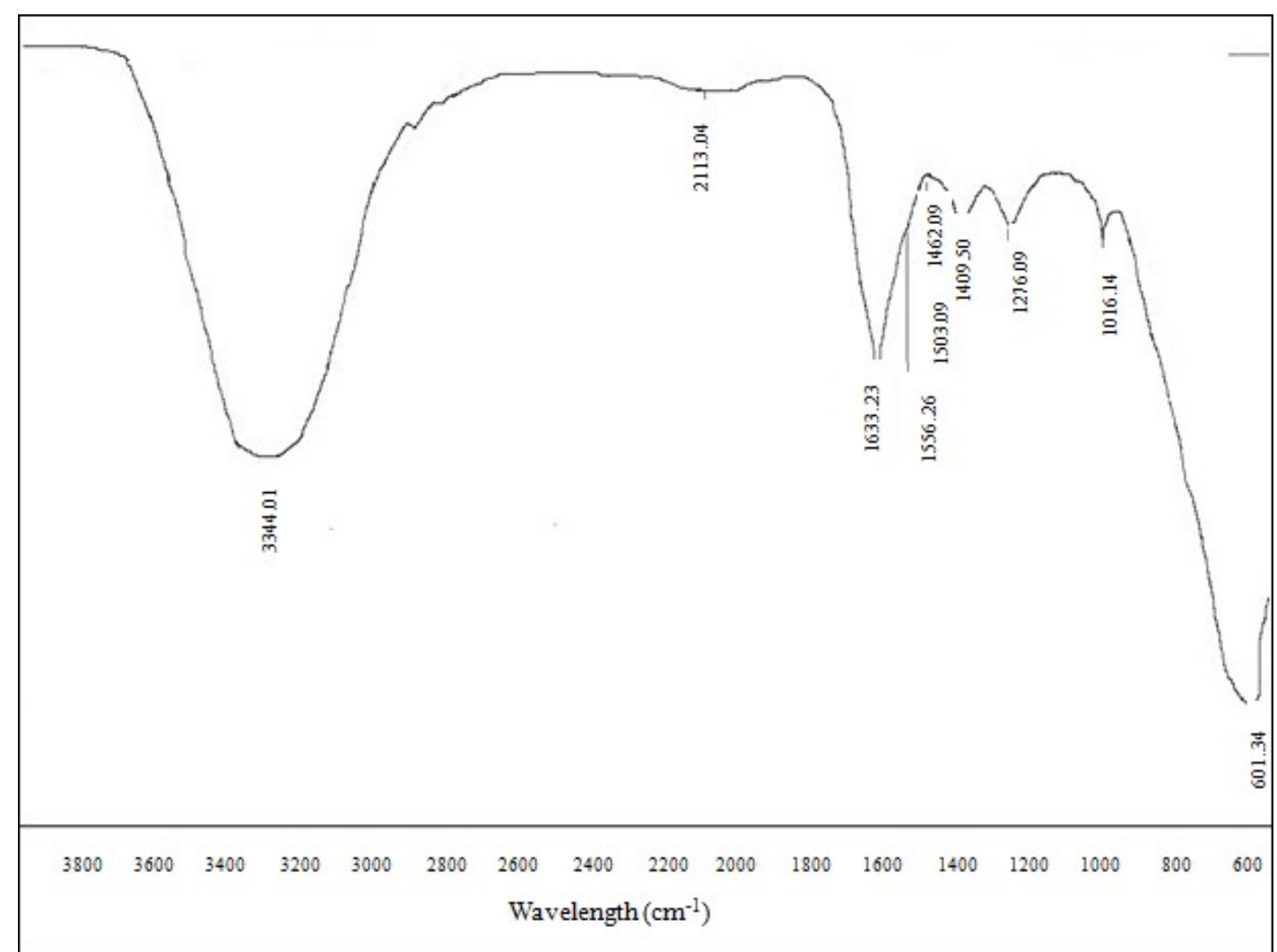

Fig 5: FTIR result of saw dust pyrolysis oil (At $500^{\circ} \mathrm{C}$ and $\mathrm{P}=10$ bar) 
Table 8: FTIR analysis of Pyrolysis oil

\begin{tabular}{|c|c|c|c|c|c|}
\hline \multirow{2}{*}{$\begin{array}{l}\text { Wave } \\
\text { number } \\
\text { (Frequ- } \\
\text { ency) } \mathrm{cm}^{-1}\end{array}$} & \multirow{2}{*}{$\begin{array}{l}\text { Group } \\
{[24]}\end{array}$} & \multirow[t]{2}{*}{ Class of compound } & \multirow{2}{*}{$\begin{array}{l}\begin{array}{l}\text { Rice } \\
\text { husk }\end{array} \\
400^{\circ} \mathrm{C} \\
10 \text { bar } \\
\end{array}$} & \multicolumn{2}{|c|}{ Saw dust } \\
\hline & & & & $\begin{array}{l}500^{\circ} \mathrm{C} \\
7 \text { bar }\end{array}$ & $500^{\circ} \mathrm{C} 10 \mathrm{bar}$ \\
\hline $3650-3100$ & O-H stretching & $\begin{array}{l}\text { Polyrimic } \\
\text { O-H water impurities }\end{array}$ & 3371.28 & 3324.55 & 3344.01 \\
\hline $3000-2800$ & C-H stretching & Alkanes & 2916.76 & 2839.69 & \\
\hline $2100-2260$ & $-\mathrm{C} \equiv \mathrm{C}-$ & Alkynes & & 2100 & 2113.04 \\
\hline $1775-1680$ & $\mathrm{C}=\mathrm{O}$ stretching & $\begin{array}{l}\text { Ketones, Aldehyde, Carboxylic } \\
\text { acid }\end{array}$ & 1704.42 & & 1633.23 \\
\hline $1575-1425$ & $\mathrm{C}=\mathrm{C}$ stretching & Alkenes & 1516.06 & & $1556.25,1503.09,1462.09$ \\
\hline $1425-1325$ & $-\mathrm{NO}_{2}$ stretching & Nitrogenous compound & 1383.47 & 1412.27 & 1409.50 \\
\hline $1300-1175$ & C-H Bending & Alkanes & 1269.31 & & 1276.09 \\
\hline $1150-1000$ & $\begin{array}{l}\mathrm{C}-\mathrm{O} \text { stretching } \mathrm{O}-\mathrm{H} \\
\text { bending }\end{array}$ & $\begin{array}{l}1^{\circ}, 2^{\circ}, 3^{\circ} \text { alcohols, Phenol, Ester } \\
\text { and Ether }\end{array}$ & 1014.93 & 1037.27 & 1016.18 \\
\hline $500-600$ & $\mathrm{C}-\mathrm{Br}$ & Alkyl Halide & 579.63 & 595.15 & \\
\hline
\end{tabular}

\subsubsection{CHNS Analysis of Solid Char}

The solid char obtained in pyrolysis was characterized by CHNS analysis. The results are shown in table 9.

Table 9: CHNS analysis of solid char obtained at different pressure and temperature conditions.

\begin{tabular}{|l|l|l|l|}
\hline \multirow{2}{*}{ Feed } & \multicolumn{3}{|l|}{ Pressure and temperature conditions } \\
\cline { 2 - 4 } & Rice husk & \multicolumn{2}{|l|}{ Saw dust } \\
\hline \multirow{2}{*}{ Elements } & $\begin{array}{l}400^{\circ} \mathrm{C} \\
10 \mathrm{bar}\end{array}$ & $\begin{array}{l}500^{\circ} \mathrm{C} \\
7 \mathrm{bar}\end{array}$ & $\begin{array}{l}500^{\circ} \mathrm{C} \\
10 \mathrm{bar}\end{array}$ \\
\hline $\mathbf{C}$ & 54.54 & 69.69 & 69.8 \\
\hline $\mathbf{H}$ & 3.940 & 4.054 & 4.270 \\
\hline $\mathbf{N}$ & 0.277 & 0.277 & 0.363 \\
\hline $\mathbf{S}$ & 0.088 & 0.188 & 0.163 \\
\hline
\end{tabular}

\subsubsection{Calorific Value of Solid Char}

The solid char obtained were analyzed by bomb calorimeter to determine its calorific value. Table 10 shows calorific value of char at various pressure and temperature conditions.

Table 10: Calorific value of solid char (saw dust).

\begin{tabular}{|c|l|l|}
\hline Sr. No. & Temperature, Pressure & Calorific value \\
\hline $\mathbf{1}$ & $400^{\circ} \mathrm{C}, 10 \mathrm{bar}$ & $13.12 \mathrm{MJ} / \mathrm{Kg}$ \\
\hline $\mathbf{2}$ & $500^{\circ} \mathrm{C}, 7 \mathrm{bar}$ & $14.21 \mathrm{MJ} / \mathrm{Kg}$ \\
\hline $\mathbf{3}$ & $500^{\circ} \mathrm{C}, 10 \mathrm{bar}$ & $14.35 \mathrm{MJ} / \mathrm{Kg}$ \\
\hline
\end{tabular}

\section{CONCLUSION}

Pyrolysis has proved to be one of the best technique for converting solid waste to useful products. The pressure and temperature have significant effect on pyrolysis. Increase in pressure favored the pyrolysis oil yield, where as increase in temperature decreased the oil yield. The maximum pyrolysis oil was obtained at high pressure (10 bar) and $500^{\circ} \mathrm{C}(27.48 \%$ for saw dust), and the FTIR results confirmed the presence of hydrocarbons in pyrolysis oil. The products obtained can be used as chemical feed stock, fuel or as energy source.

\section{REFERENCES}

[1] PÜTÜN, A.E.E., et al., Fixed-Bed Pyrolysis of Cottonseed Cake: Product Yields and Compositions. Energy Sources, 1997. 19(9): p. 905-915.

[2] Tsai, W.T., Y.H. Chou, and Y.M. Chang, Progress in energy utilization from agrowastes in Taiwan. Renewable and Sustainable Energy Reviews, 2004. 8(5): p. 461-481.

[3] Demirbaş, A., Biomass resource facilities and biomass conversion processing for fuels and chemicals. Energy Conversion and Management, 2001. 42(11): p. 13571378.

[4] Pereira, J., F.A. Agblevor, and S.H. Beis, The Influence of Process Conditions on the Chemical Composition of Pine Wood Catalytic Pyrolysis Oils. ISRN Renewable Energy, 2012. 2012: p. 9.

[5] Biswal, B., S. Kumar, and R.K. Singh, Production of Hydrocarbon Liquid by Thermal Pyrolysis of Paper Cup Waste. Journal of Waste Management, 2013. 2013: p. 7. 
[6] Shaaban, A., et al., Influence of heating temperature and holding time on biochars derived from rubber wood sawdust via slow pyrolysis. Journal of Analytical and Applied Pyrolysis, 2014. 107: p. 31-39.

[7] Fukuda, S., Pyrolysis investigation for bio-oil production from various biomass feedstocks in Thailand. International Journal of Green Energy, 2015. 12(3): p. 215-224.

[8] Demirbas, M.F., Current Technologies for Biomass Conversion into Chemicals and Fuels. Energy Sources, Part A: Recovery, Utilization, and Environmental Effects, 2006. 28(13): p. 1181-1188.

[9] Lu, R., et al., Fractional characterization of a bio-oil derived from rice husk. Biomass and Bioenergy, 2011. 35(1): p. 671-678.

[10] Williams, P.T. and S. Besler, The pyrolysis of rice husks in a thermogravimetric analyser and static batch reactor. Fuel, 1993. 72(2): p. 151-159.

[11] Li, L., H. Zhang, and X. Zhuang, Pyrolysis of Waste Paper: Characterization and Composition of Pyrolysis Oil. Energy Sources, 2005. 27(9): p. 867-873.

[12] Islam, A.K.M.S., et al., 5th BSME International Conference on Thermal EngineeringA Comparative Study on Pyrolysis for Liquid Oil from Different Biomass Solid Wastes. Procedia Engineering, 2013. 56: p. 643-649.

[13] Punsuwan, N. and C. Tangsathitkulchai, Product characterization and kinetics of biomass pyrolysis in a three-zone free-fall reactor. International Journal of Chemical Engineering, 2014. 2014.

[14] Zeng, D., et al., 2011 2nd International Conference on Advances in Energy Engineering (ICAEE)The Experimental Study on Pyrolysis of the Cassava Rhizome in the Large Scale Metal Kiln Using Flue Gas. Energy Procedia, 2012. 14: p. 1684-1688.

[15] Ma, Z., et al., Study of the fast pyrolysis of oilfield sludge with solid heat carrier in a rotary kiln for pyrolytic oil production. Journal of Analytical and Applied Pyrolysis, 2014. 105: p. 183-190.

[16] Pradhan, D. and R. Singh, Thermal pyrolysis of bicycle waste tyre using batch reactor. International Journal of Chemical Engineering and Applications, 2011. 2(5): p. 332.

[17] Chaiya, C. and P. Reubroycharoen, Production of Bio Oil from Para Rubber Seed Using Pyrolysis Process. Energy Procedia, 2013. 34: p. 905-911.

[18] Soetardji, J.P., et al., Bio-oil from Jackfruit Peel Waste. Procedia Chemistry, 2014. 9: p. 158-164.

[19] Guo, X., et al., Properties of Bio-oil from Fast Pyrolysis of Rice Husk. Chinese Journal of Chemical Engineering, 2011. 19(1): p. 116-121.

[20] Smets, K., et al., Flash pyrolysis of rapeseed cake: Influence of temperature on the yield and the characteristics of the pyrolysis liquid. Journal of Analytical and Applied Pyrolysis, 2011. 90(2): p. 118125.

[21] Williams, P.T. and N. Nugranad, Comparison of products from the pyrolysis and catalytic pyrolysis of rice husks. Energy, 2000. 25(6): p. 493-513.
[22] Yu, J., et al., Effect of Pressure on Char Formation during Pyrolysis of Pulverized Coal. Energy \& Fuels, 2004. 18(5): p. 1346-1353.

[23] Melligan, F., et al., Pressurised pyrolysis of Miscanthus using a fixed bed reactor. Bioresource technology, 2011. 102(3): p. 3466-3470.

[24] Islam, M.N., M.N. Islam, and M.R.A. Beg, The fuel properties of pyrolysis liquid derived from urban solid wastes in Bangladesh. Bioresource Technology, 2004. 92(2): p. 181-186. 